УДК $78.03+784.3$

\title{
Цао Хе
}

аспирант кафедры теории музыки и фортепиано

Харьковской государственной академии культуры odma_n@ukr.net

\section{СПЕЦИФИКА КОМПОЗИТОРСКОЙ ИНТЕРПРЕТАЦИИ РОМАНА В. ГЮГО «СОБОР ПАРИЖСКОЙ БОГОМАТЕРИ» В ВОКАЛЬНОЙ БАЛЛАДЕ ШАН ДЕИ}

Цель исследования - раскрыть специфику композиторской интерпретации романа В. Гюго «Собор Парижской Богоматери» в вокальной балладе Шан Деи на прозачческий текст Чжи Тун. Научная новизна исследования заключается в том, что в нем впервые баллада Шан Деи рассмотрена в аспекте расширения традиционных для вокального искусства Китая тематики и принципов музыкальной драматургии. Методология исследования основывается на сочетании аналитического, литературоведческого и жканрового подходов. Выводы. Специфика композиторской интерпретации романа В. Гюго в балладе китайского композитора Шан Деи заключается в перетрактовке литературного первоисточника как вербального прообраза музыкально-словесной целостности (устранения событийности, фабульности, сюжетности с иелью концентрированного изложения концепции сочинения) и сохранении романности как принципа драматургии. Выявлена смысловая многозначность лейтмотивов «франиузской баллады» - колокола, фатума, авторского повествования, любви/ненависти, таниа умершей Возлюбленной. Со звоном колокола связывает композитор оформление метафорических рядов баллады, метаморфозы присущего ему символического смысла.

Ключевые слова: композиторская интерпретация, вокальная баллада, принцип романности музыкальной драматургии, лейтмотив.

Cao Xe, graduate student of the of the Theory of music and piano department of The Kharkiv State Academy of Culture

Specificity of composer's novel interpretation of Victor Hugo "Notre-Dame de Paris»in vocal ballad of Shang Dei

The purpose of research - to reveal the specifics of the composer's interpretation of Victor Hugo's novel «Notre Dame de Paris» in the vocal ballad of Shang Dei on the prose text of Zhi Tong. The scientific novelty of the research lies in the fact that for the first time Ballad of Shang Dei was considered in the aspect of expansion of the traditional Chinese vocal art themes and principles of the musical drama. The research methodology is based on a combination of analytical, literary and genre approaches. Conclusions. The specificity of the composer's interpretation of the novel of Victor Hugo in the ballad of Chinese composer 
Shang Dei consists in reinterpretation of literary source as the inverse image of the verbal-prototype of musical fictional integrity (eliminating of eventness, $\mathrm{fa}$ ble, plot with a view of the concentrated presentation of the work'sconcept) and maintaining the principle of the novel as a drama. The semantic ambiguity of the leitmotifs of the "French ballads» is revealed - bell, fate, the author'snarration, love / hate, dance of the dead Beloved. The ringing of the bells is associated by the composerwith clearance of metaphorical ballads series, the metamorphosis of its inherent symbolic meaning.

Keywords: composer's interpretation, vocal ballad, principle of Romannizm, musical drama, the leitmotif.

Цао Хе, аспірант кафедри теорії музики і фортепіано Харківської державной академії культури

Специфіка композиторської інтерпретації роману В. Гюго «Собор Паризької Богоматері» у вокальній баладі Шан Деї

Мета дослідження - розкрити специфіку композиторської інтерпретації роману В. Гюго «Собор Паризької Богоматері» у вокальній баладі Шан Деї на прозаїчний текст Чжі Тун. Наукова новизна дослідження полягає у тому, що у ньому вперше балада Шан Деї розглянута в аспекті розширення традиційних для вокального мистецтва Китаю тематиці та принципів музичної драматургії. Методологія дослідження базуеться на поєднанні аналітичного, лутературознавчого та жанрового підходів. Висновки. Специфіка композиторської інтерпретації роману В. Гюго у баладі китайського композитора Шан Деї полягає у перетрактовці літературного першоджерела як вербального прообразу музично-словесної цілісності (відмова від дієвості, фабульності, сюжетності з метою концентрованого викладення концепції твору) $i$ збереженні романності як принципу драматургії. Виявлено смислову багатозначність лейтмотивів «рраниузької балади» - дзвонів, фатуму, авторської оповідальності, кохання/ненависті, танцю померлої Коханої. Із дзвонами композитор пов'язує оформлення метафоричних рядів балади, метаморфози властивого їм символічного змісту.

Ключові слова: композиторська інтерпретація, вокальна балада, принцип романності музичної драматургії, лейтмотив.

Актуальность темы. Изучение взаимодействий традиций Востока и Запада в художественной культуре современности - одно из фундаментальных направлений отечественной музыкальной науки. Среди жанровых сфер китайской музыки XX-XXI столетия, в которых проявилось взаимодействие художественных принципов европейской и национальной культур, песне и ее жанровым разновидностям принадлежит особая роль. В песне обогащение китайской музыкально-поэтической культуры посредством приобщения к традициям ев- 
ропейской песенной традиции происходит особенно плодотворно. Многообразие художественных возможностей песенного жанра в китайской культуре, путей взаимодействия с европейской песенной традицией, обусловливает возникновение оригинальных ракурсов научного осмысления песни как жанровой субстанции. Композиторская интерпретация европейского прозаического первоисточника в песне китайского композитора до сих пор оставалась вне сферы внимания отечественных исследователей. Данное художественное «поле» - оригинальный материал для изучения проблемы взаимодействия традиций европейского и китайского искусства, позволяющий выявить уровни синтеза, что до сих пор не становились предметом специального исследования.

Выявление специфики композиторской интерпретации романа В. Гюго «Собор Парижской Богоматери» в вокальной балладе Шан Деи представляет собой актуальную задачу современного музыковедения, поскольку позволяет осмыслить специфику трактовки шедевра французской литературы китайским композитором.

Цель исследования - раскрыть специфику композиторской интерпретации романа В. Гюго «Собор Парижской Богоматери» в вокальной балладе Шан Деи на прозаический текст Чжи Тун.

Научная новизна исследования заключается в том, что в нем впервые:

- баллада Шан Деи рассмотрена в аспекте расширения традиционных для вокального искусства Китая тематики и принципов музыкальной драматургии;

- выявлена специфика композиторской интерпретации французского романа в китайской фокальной балладе (удвоение интерпретации);

- установлено своеобразие романности как художественного принципа баллады Шан Деи;

- определены особенности композиторской трактовки иллюзорного образа;

- представлен анализ лейтмотивов музыкальной драматургии баллады;

- осмыслена специфика художественного истолкования философской концепции «красоты в молчании» («беззвучной музыки») в вокальной балладе Шан Деи.

В песенном творчестве Шан Деи (композитора, творческий расцвет которого связан с рубежом XX-XXI веков) взаимодействуют 
взаимосвязанные тенденции. Одна из них обусловлена развитием традиций песенного искусства Китая XX века, другая - формированием его новаторских свойств. Расширение традиционной для вокального искусства Китая тематики в творчестве Шан Деи сопряжено с поиском новаторских средств музыкальной выразительности.

Нововведением Шан Деи в области вокальной лирики стало обращение к фрагментам объемных литературных произведений, философско-концепционному обобщению их содержания, краткому переизложению развернутого прообраза. Жанр литературного произведения, вовлекаемого Шан Деи в музыкально-словесную целостность в качестве «канвы» ее вербального прообраза, трансформированного с целью соответствия жанрово-стилевой системе вокального искусства, представляет собой роман (новеллу, повесть). Принципы перетрактовки литературного первоисточника как прообраза вербального текста музыкально-словесной целостности в творчестве Шан Деи едины: сжатие содержания романа за счет устранения событийности, фабульности, сюжетности, действенности; концентрированное, обобщенное изложение концепции сочинения. Опоэтизированное переложение концепции литературного прообраза являет собою новое художественное произведение, созданное на основе творческого переосмысления оригинала. Трактовка литературного прообраза как основы музыкально-поэтического произведения соответствует критериям национальной поэзии (отсутствие фабульности, сюжетности), что утвердились на протяжении тысячелетий.

Вокальные произведения композитора, вербальные тексты которых написаны на основе творческого переосмысления прозаического первоисточника, отличает удвоение интерпретации (удвоенная интерпретация), включающей в себя поэтический и композиторский «срезы». Романность обретает значение принципа, организующего смыслообразование вокальных произведений Шан Деи на основе переосмысления маситабных литературных первоисточников.

Шан Деи не ограничивается привлечением в качестве литературного прообраза музыкально-словесного произведения образцов китайской прозы, расширяя традиционную тематику песенного творчества Китая XX века, основывающегося, преимущественно, на национальных образцах. Одна из вокальных баллад написана на основе концепционно-поэтического переизложения романа «Собор Парижской Богоматери» В. Гюго. Если до сих пор для китайского вокального искусства XX века характерной чертой являлось подключе- 
ние жанрово-стилевых черт европейской музыки, то Шан Деи вовлек в балладу по В. Гюго (прозаический текст Чжи Туна) и европейскую образно-смысловую основу.

Содержание романа В. Гюго на уровне идей и проблем соответствует духу китайского музыкального романтизма, национальной вокальной лирики XX века. Об этом свидетельствует интерпретация тем романа: трактовка созерцания как способа постижения мира, одиночества как свидетельства исключительности героя, душа которого чутко откликается на горести и радости окружающего бытия. Вместе с тем темы и образы, обладая чертами связи с национальной китайской традицией, во многом не согласуются с ее основами. Об этом свидетельствует, например, повышенная эмоциональность, характеризующая внутренний мир героев В. Гюго, трактовка темы любви, выходящая за пределы характерного для классической китайской поэзии ее понимания как воплощения супружеской привязанности, метод гротеска в отображении образа Квазимодо, событийность действия.

Если для китайской художественной песни характерно пребывание в русле национальной поэтической традиции, то Шан Деи расширяет сферу национального романтизма, вовлекая в него не только музыкальную, но и словесную основу вокального произведения. Подобно тому, как Чжан Чжоу в 1920-е годы утверждал, что любое произведение, созданное китайским композитором на основе закономерностей инонационального музыкального жанра и языка, останется китайским, так и баллада Шан Деи, возникшая вследствие музыкально-литературной интерпретации французского романного первоисточника, представляет собой образец китайского музыкально-поэтического искусства рубежа XX-XXI веков.

Свойства музыкально-поэтической драматургии баллады Шан Деи обусловлены художественным миром романа В. Гюго. Композитор выходит за пределы традиций китайского искусства, обусловленных национальными эстетическими концепциями музыки. В китайскую балладу проникает инопространственная среда, обрисованная первой строкой: «Франция. Париж. Нотр-Дам», придающей произведению черты географического комментария. При этом время действия баллады не уточняется: содержание обретает надвременной характер, устремляясь к вечности. Этому способствует музыкальный символ колокола и связанная с ним сумма значений.

За небольшим по протяженности музыкально-литературным текстом вокальной баллады, благодаря системе скрытых и явных 
ассоциаций, возникает содержательный «массив» романа В. Гюго. «Транспонированный» в план вокальной баллады шедевр французской литературы сохраняет в новых жанровых условиях романный «макроскопический» размах вследствие ассоциативных связей с прообразом. Хотя масштаб «французской баллады» Шан Деи превышает «объем» вокальной миниатюры XX века (таковая охватывает нередко менее 20 тактов), тем не менее, сопоставление музыкально-поэтического произведения с романом В. Гюго свидетельствует о миниатюризации литературного прообраза, его многократном «уменьшении». В результате балладе Шан Деи оказывается свойственным принцип китайской художественной песни: соотношение планов миниатюры и макрокосма [5]. Своеобразие авторской интерпретации данного принципа в балладе Шан Деи заключается в трактовке макрокосма как Вселенной, в функции которого по отношению к балладе предстает роман В. Гюго, в художественном времени-пространстве которого, согласно концепции «эстетизированного хаоса» Ф. Шеллинга и Ф. Шлегеля [4], осуществляется романтическое «смешение» высокого и низкого, трагического и комического, сакрального и профанного, культового и карнавального, «ученого стиля» и вольгаре.

Жанровая модуляция - трансформация романа В. Гюго в вокальную балладу - наряду со сменой жанрового имени (а, следовательно, и сущностных формо- и смыслообразующих параметров), позволила сохранить основополагающие свойства первоисточника: повествовательность, единство лирического и драматического начал, взаимопроницаемость изобразительного и выразительного, сочетание принципов фрагментарности и сквозной драматургии, глубинность и парадоксальность взаимодействующих символов. Единство художественных целостностей обусловлено их принадлежностью к эпосу как роду искусства и романтизму как художественному методу. В романе и балладе многообразие содержания объединено единством повествовательного тона, художественного мировосприятия. Как и роман, вокальная баллада Шан Деи представляет собой рассказ о любви, побежденной ненависти и смерти. И в романе, и в вокальной балладе наблюдается взаимодействие трактовок рассказа как эпического тона романного (балладного) повествования от лица автора, и как изложения, ведущегося из уст того или иного героя произведений. В романе таких рассказчиков, периодически выполняющих функцию повествователя, достаточно много: это и сам автор, и старуха, добровольно заточившая себя в «Крысиную нору», и священник, 
сыгравший судьбоносную роль в жизни Квазимодо и Эсмеральды. В вокальной балладе, помимо автора, в роли рассказчика предстает колокол, повествующий о трагической судьбе звонаря, «похоронившего в сердце ненависть» во имя любви. Если в романе повествования от лица того или иного героя нередко обретают значение «вставных повестей», способствуя преумножению черт эпической драматургии, то вокальной балладе свойственна недифференцированная трактовка голоса автора балладного повествования и колокола как рассказчика о судьбе Героя: повествование колокола «вписано» в рассказ от автора («колокол рассказывает о том...»). Так возникает своеобразная трактовка романтического приема «рассказ в рассказе».

Во «французской балладе» Шан Деи крупным планом представлена смыслообразующая линия романа - освященная колокольным звоном любовь и смерть Героя, символизирующего восходящее к гротеску противоречивое единство внешнего безобразия и внутренней красоты, душевной боли и любви, «похоронившего в своей душе ненависть», чтобы сопроводить в последний путь Возлюбленную («Цыганскую девушку»).

О стремлении композитора к предельному обобщению и универсализации содержания романа в вокальной балладе свидетельствует следующий принцип композиторской интерпретации литературного первоисточника. Избегая вводить в балладу имена собственные, что способствовало бы конкретизации действующих лиц, Шан Деи сохраняет свойственные героям романа имена-функции (сакральные апеллятивы): звонарь и цыганская девушка. Композиторская трактовка этих образов парадоксальна. Лейтмотивом безмолвствующего героя в балладе становится колокольный звон - то мощный, подобный грому, то едва слышный; лейтмотивом мертвой цыганской девушки - ритмоформула танцевального характера, имеющая реминисцентное значение (воспоминание об угасшей жизни), обретающая семантику Danse macabre. Помимо портретных характеристик, два центральных лейтмотива вокальной баллады порождают систему взаимосвязанных образов-символов.

Раскрывая сущность отмеченной романтическим пафосом темы Liebestod, Шан Деи сохраняет в балладе важнейшие образы-символы романа В. Гюго, придавая им оригинальное художественное прочтение.

Смыслообразующее значение во «французской балладе» Шан Деи имеет образ колокола. Его звучание определяет процесс конструи- 
рования формы и содержания, оформление метафорических рядов баллады, метаморфозы символического смысла. Колокольный звон в композиторской интерпретации Шан Деи - звуковой символ художественного «поля» романа В. Гюго, Франции, Парижа, собора Нотр-Дам, европейской цивилизации. Звук колокола ассоциируется с образом звонаря, без которого дыхание собора невозможно, столь же одинокого, как и шедевр готической архитектуры. Звук колокола символизирует бессмертие души собора и смерть героя, любовь и биение его сердца, то стучащего с неистовой силой, подобно грому, то холодеющего, останавливающегося в финале баллады. В звуках колокола в балладе Шан Деи сливается изобразительное (имитация колокольного звона в вокальной партии - «тан, тан») и символическое.

Проявление философской традиции китайского искусства, связанной с воссозданием иллюзорного образа, наблюдается в процессе становления музыкальных образов колокола, звонаря и умершей цыганской девушки. Превращение образа колокола/звонаря в ирреальный (иллюзорный) образ происходит после того, как сердце героя остановилось, когда он торопливо устремляется в посмертный путь по дороге, по которой ранее отправилась душа его умершей Возлюбленной («спешит сопроводить мертвую цыганскую девушку»). Завершающий повествование вокализ (оплакивание героя) и кода-прощание (посмертный путь спешащего вослед Возлюбленной героя) содержат реминисцентно представленные отзвуки лейтмотива колокола/звонаря.

Звуковая трактовка образа умершей цыганской девушки, вослед которой спешит верный Квазимодо, связана с реминисцентным методом (композитор представляет данный образ сквозь призму воспоминаний, после того, как смерть простерла над ней свои черные крылья). Поскольку экспозиционность в отображении образа возлюбленной звонаря отсутствует, композиторской интерпретации изначально свойственны черты воспоминаний, иллюзорности, призрачности. Сопряженный с танцевальной ритмоформулой (символом души Эсмеральды), музыкальный образ цыганской девушки воплощен на основе жанровых черт танца умершей танцовщицы (по аналогии с «Паваной умершей инфанты» М. Равеля), обретая значение Danse macabre. Танцевальная ритмоформула символизирует также и «горячую любовь» Квазимодо, что свидетельствует о ее полифункциональности.

Шан Деи переосмысливает сущность восходящей к конфуцианству философско-эстетической концепции возникновения музыки 
из непроявленного (Дао), из тишины, молчания, «великого безмолвия», отраженной в жанре китайской художественной песни (см. песни Чжао Юань Женя, Ли Инхая, основанные на традиции воспевания идеализированной тишины [5]). В отличие от философской традиции в балладе Шан Деи музыка рождается вместе с мощным ударом колокола в фортепианной прелюдии (кульминация-источник). Как символ единства божественного и человеческого начал колокол воплощает идею связи художественного мира баллады с космическим началом, придавая ее содержанию сакральный оттенок. Волновая драматургия баллады (колокольные кульминации обрамляют среднюю часть баллады - вплоть до начала вокализа и коды) может быть уподоблена звуковой амплитуде колокола. Три кульминационные зоны в музыкальной драматургии баллады трактованы композитором на основе взаимодействия внешнего и внутреннего миров, взаимопроницаемости образов ударов колокола и биения сердца.

Вместе с тем конфуцианская концепция красоты в молчании также нашла отражение в вокальной балладе по роману В. Гюго. Не музыка как таковая, но музыкальное повествование рождается в вокальной балладе из тишины $(\boldsymbol{m p})$. В атмосферу тишины погружается финальный раздел баллады, ее послесловие (вокализ и кода-прощание). В итоге в балладе специфически воссоздана философская идея сакрализации тишины, рождения музыки из Дао (непроявленного). Наряду с применением характерных для вокальной музыки китайских композиторов XX века динамических оттенков, редко превышающих $\boldsymbol{m} \boldsymbol{p}$, Шан Деи тяготеет к формированию мощных кульминационных зон в драматургии вокальной баллады, соотнося их с sff и $f$.

Образ колокола предстает в роли того связующего начала, что объединяет далекие во времени и пространстве европейскую и китайскую цивилизации. Для каждой колокол - воплощение сакрального времени-пространства, образ, посредством которого осуществляется связь земного и небесного, человеческого и божественного, вселенского. Композиторская интерпретация музыкального образа колокола в вокальной балладе Шан Деи оригинальна в контексте китайской традиции. Если удары колокола в ряде китайских художественных песен XX века символизировали доносящиеся издалека звуки, отдающиеся в душе лирического героя, то в вокальной балладе, помимо сохранения традиционного подхода, колокольный звон порождает подобный грому «большой звук», становясь символом трагической судьбы звонаря, передавая его волнение («этот 
звук вызывает волнение»), «его горячую любовь». В музыкальной трактовке звука колокола как воплощения титанической мощи очевидно влияние европейских традиций. Наряду со следованием национальной традиции здесь очевидна и европейская трактовка колокола. Китайский композитор сообщает образу колокола множественность значений. Колокол трактован как вестник небес, возвещая начало и конец жизни героя. Со звуком колокола композитор связывает идею его соответствия этапам жизни лирического героя сочинения (подобно кантате «Колокола» С. В. Рахманинова). Колокольный звон сопровождает героя баллады Шан Деи на всех этапах жизни как символ его судьбы, способствует формированию его музыкального портрета, символизирует то бурное, то замирающее биение сердца, обрисовывает состояния одиночества, отчаяния, любви, исцеления от ненависти («он похоронил в сердце ненависть»), освящает его последний путь. Звук колокола замирает вместе с последними ударами сердца героя, сопроводившего в небытие «мертвую цыганскую девушку».

Драматургия вокальной баллады Шан Деи насыщена лейтмотивами, семантизирующими развитие музыкального действия. Лейтмотивы колокола (собора, звонаря, биения сердца), рока (судьбы, смерти), авторского повествования, «мертвой цыганской девушки» (посмертного танца Эсмеральды), любви-ненависти взаимодействуют в музыкальной драматургии баллады, образуя смысловые контрапункты. Сформировавшись в фортепианной прелюдии, лейтмотивы обретают смысловую конкретизацию в вокальном разделе благодаря вербальному ряду, сопряженностью с тем или иным ключевым словом вербального текста, что способствовало расшифровке их содержания. Например, на грани 21-22 тактов слово «колокол» предваряет «картину пробуждения колокола» - вторую волну кульминации в балладе (интонационно соотносима с двумя первыми «ударами колокола» в фортепианной прелюдии). Речитации на одном звуке в вокальной партии соответствуют словосочетанию «трагическая судьба» (рок, фатум) в вербальном тексте. Танцевальная ритмоформула, введенная в партию фортепиано на словах «мертвая цыганская девушка», способствовала определению ее значения как музыкального символа посмертного танца Эсмеральды, света ее души, отраженного в иллюзорном танце. Предваряемые восходящим скачком и «роковыми» речитациями на одном тоне нисходящие ходы в вокальной партии связаны со словами о ненависти, побежденной любовью (завер- 
шающее балладное повествование построение), обретают значение лейтмотива любви-ненависти - Liebeshass.

Всеприсутствие лейтмотива рока (фатума, судьбы) в музыкальной драматургии баллады обусловлено тем, что его интонационные особенности в трансформированном виде обнаруживаются в лейтмотивах колокола, посмертного танца Эсмеральды, любви-ненависти. Столь весомая роль лейтмотива судьбы в балладе обусловлена значением, ниспосланным Року в романе В. Гюго. Во Вступлении к роману обусловлена причина его появления. Начертанное «в темном закоулке одной из башен» собора Парижской Богоматери слово «РОК», мрачный смысл которого поразил писателя $[1,155]$, согласно признанию автора романа, «породило настоящую книгу» $[1,156]$. Подобно тому, как развитие действия романа и судеб его героев предопределил рок, так и интонационную драматургию французской баллады Шан Деи сформировала семантическая наполненность лейтмотива рока, скрывающаяся под разными «личинами», пронизывающая музыкально-вербальное сочинение.

Сообщение лейтмотиву авторского повествования сквозной интонационно-драматургической функции в оформлении содержания баллады обусловлено осознанием значительности роли Автора и авторских монологов в романе В. Гюго. Посредством авторских монологов в романе представлено описание собора, внутреннего и внешнего действия, осуществлено соединение различных по стилю фрагментов и этапов повествования, выражено чувство сострадания к героям как носителям трагического содержания произведения. Во «французской балладе» Шан Деи лейтмотив авторского повествования, подобно литературному первоисточнику, способствует объединению эпизодов произведения, содержит композиторскую оценку драмы. Интонационно-образное оформление лейтмотива авторского повествования в вокальной балладе представляет собой арфообразное движение 16-ми длительностями в партии фортепиано, что позволяет соотнести его с функцией струнно-щипкового инструмента, сопровождавшего повествование певца-сказителя как в европейской, так и в китайской традициях. Трактовка лейтмотива авторского голоса также способствует достижению единства западного и восточного времени-пространства.

Отличительной чертой интонационной драматургии баллады является сопряженность лейтмотивов с системой функций и значений. Так, лейтмотив колокола является звуковым аналогом образов собора 
(главного героя романа В. Гюго) и его звонаря, биения сердца героя как отражения связанной с ним внутренней драмы. Лейтмотив рока, вызревая постепенно, объединяет в интонационную группу лейтмотивы колокола (собора, звонаря) и посмертного танца Эсмеральды, обретая в итоге своеобразный интонационно-семантический «облик». Речитации лейтмотива судьбы включены в состав лейтмотива любви-ненависти, что означает развитие темы обреченности любви, победившей ненависть. Лейтмотив посмертного танца Эсмеральды (в партии фортепиано) звучит в контрапункте с лейтмотивами рока и любви-ненависти. Смысловой контрапункт тем-символов свидетельствует об их глубинном взаимопроникновении. Проведение лейтмотива авторского повествования в контрапункте с лейтмотивом колокола позволяет сделать вывод о сообщении колоколу функции рассказчика. Лейтмотив авторского голоса, помещенный между кластерами, символизирующими удары колокола, обретает дополнительное выразительно-смысловое значение, символизируя звуковые раскаты, сопровождающие колокольный звон.

Интонационная драматургия, основанная на перетекании одного лейтмотива в другой, постоянное преобразование свойственных им значений, возникновение новых смысловых аспектов в результате интонационных трансформаций лейтмотивных комплексов позволяют сделать вывод о преломлении во «французской балладе» Шан Деи вагнеровской концепции «бесконечной мелодии» [3].

Лейтмотив любви-ненависти объединяет внутренне конфликтные состояния Героя. Интонационное единство смыслообразов любви и ненависти определяло музыкальную драматургию оперы Р. Штрауса «Саломея». В балладе Шан Деи наблюдается синтез традиций романтической и экспрессионистской музыкальных драм, вагнеровской и штрауссовской тем - Liebestod и Liebeshass.

Из лейтмотива колокола проистекает интонационное действо баллады; лейтмотиву авторского повествования присуща драматургическая функция «сплетения» этапов фрагментарно организованного балладного целого.

Пять лейтмотивов баллады - колокола, повествования от лица автора, любви-ненависти, посмертного танца Эсмеральды, судьбы (рока) экспонированы в фортепианной прелюдии - прологе балладного действия, интонационной матрице, концентрированно смысловой потенциал произведения. Прелюдия предвосхищает динамический план развития баллады: ее открывает кульминация-источник 
(аккорды $s f f)$, а завершает уступообразный динамический спад, приводящий к $m p$. Аналогом соотношения инструментального вступления и драмы в балладе Шан Деи предстает опера Р. Вагнера «Летучий голландец». Ее увертюра, подобно фортепианной прелюдии баллады, предваряет этапы интонационной драматургии оперы. Поскольку опера байройтского гения обладает жанровыми чертами баллады, а ее увертюра предстает в качестве баллады симфонической, структурнофункциональные, содержательно-композиционные свойства «французской песни» Шан Деи подчеркивают ее связи с романтической балладой XIX века, претворенной в жанре оперы.

Громогласные аккорды, символизирующие колокольный звон (тт. 1-2); арфообразный фрагмент темы авторского повествования (вторая половина 2 т.); лейтмотив любви-ненависти, проводимый в контрапункте с темой колокола в басовом регистре; основанный на танцевальной ритмоформуле лейтмотив умершей цыганки; представляющий собой речитацию на одном звуке лейтмотив рока (фатума, судьбы) - таков план интонационной драматургии фортепианной прелюдии, развитый в балладном действии.

Выводы. Музыкальная драматургия баллады основана на восходящем к европейскому романтизму единстве принципов сквозной драматургии и фрагментарности, характерных для Durhcompanierenliede, что свидетельствует о балладности произведения Шан Деи [4].

Три динамических волны вокальной баллады Шан Деи обладают общим конструктивным планом: громоподобная кульминация-источник (sff), пребывание в кульминационной зоне (от 2 до 9 тт.), постепенное (террасообразное) затихание звучности (до $m p$ ).

В вокализе, разделяющем (соединяющем) балладное действие и коду-прощание, согласно традициям китайской вокальной лирики XX столетия, воплощена конфуцианская идея превосходства невыразимого содержания над его словесным выражением, преобладания невысказанного над сказанным, чувства над словом. Поэтизация невысказанного в коде баллады способствует раскрытию конфуцианской идеи. Мелодия вокализа основана на трансформации лейтмотива любви-ненависти. Так в балладе утверждается философская идея превосходства несказанного над выраженным словами. Вокализ представляет собой три волны мелодического ниспадания, расположенных секвенционно (по тонам вниз). Помещение начального звена секвенции на ч.5 выше интонационного прообраза («Этот звук передает его горячую любовь») придает вокализу особую напряжен- 
ность (фортепианная партия основана на взаимодействии лейтмотивов колокола и повествования от автора).

Развертывание коды-прощания (реминисценции) приводит к замиранию ударов колокола-сердца: навеки замолчавший собор погружается в безмолвие, беззвучную вечную музыку, исторгаемую Дао.

«Французская баллада» Шан Деи являет собой звуковую картину жизни и смерти, начертанную рукой талантливого Мастера на основе сочетания традиций художественных культур Запада и Востока.

\section{СПИСОК ЛИТЕРАТУРЫ}

1. Гюго В. Собор Парижской Богоматери. Собр. соч.: в $6 \mathrm{~m}$. Т. 1. М.: Правда, 1988. C. $155-651$.

2. Краузе Э. Рихард Штраус. Образ и творчество. М.: Музгиз, 1961. 611 с.

3. Курт Э. Романтическая гармония и ее кризис в «Тристане» Вагнера. М.: Музыка, 1975. 544 с.

4. Рощенко Е. Новая мифология романтизма и музыка (проблемы энциклопедического анализа музыки). Харьков: ХНУРЭ, 2004. 288 с.

5. У Хун Юань. Китайская художественная песня: история и теория жанра: дис. ... канд. искусствоведения: 17.00.03. Харьков, 2016. 250 с.

\section{REFERENCES}

1. Hugo, V. (1988). Notre Dame Cathedral. Coll. op. in 6 vols. Vol. 1. M.: True, P. 155-651 [in Russian].

2. Krause, E.(1961). Richard Strauss. Image and creativity. M.: Muzgiz [in Russian].

3. Kurt, E. (1975). Romantic harmony and its crisis in Tristan Wagner. Moscow: Music, [in Russian].

4. Roshchenko, E.(2004). New mythology of Romanticism and music (problems of encyclopedic analysis of music). Kharkov: KHNUREb[in Russian].

5. Wu Hong Yuan (2016). Chinese art song: history and theory of the genre. Candidate'sthesis - Kharkov [in Russian].

Стаття надійшла до редакиії 01.03.2017

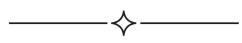

